Article

\title{
Research on the Driving Factors for the Development of Inclusive Finance in Rural Commercial Banks: Market Competition or Government Intervention?
}

\author{
Chenlu Zhu ${ }^{1}$, Xiaolin Dong ${ }^{1, *}$, Liren Ding ${ }^{1}$ and Chen Lin ${ }^{2}$ \\ 1 School of Finance, Nanjing Agricultural University, Nanjing 210095, China; 2017218008@njau.edu.cn (C.Z.); \\ 2018218001@njau.edu.cn (L.D.) \\ 2 Financial Management Service Branch, South Australia Police Department, Adelaide, SA 5000, Australia; \\ chenlin1457@outlook.com \\ * Correspondence: dongxiaolin@njau.edu.cn
}

Citation: Zhu, C.; Dong, X.; Ding, L.; Lin, C. Research on the Driving Factors for the Development of Inclusive Finance in Rural Commercial Banks: Market Competition or Government Intervention? Businesses 2022, 2, 1-18. https://doi.org/10.3390/businesses 2010001

Academic Editor: Lester Johnson

Received: 18 August 2021

Accepted: 25 November 2021

Published: 23 December 2021

Publisher's Note: MDPI stays neutral with regard to jurisdictional claims in published maps and institutional affiliations.

Copyright: (c) 2021 by the authors. Licensee MDPI, Basel, Switzerland. This article is an open access article distributed under the terms and conditions of the Creative Commons Attribution (CC BY) license (https:// creativecommons.org/licenses/by/ $4.0 /)$

\begin{abstract}
Based on the survey data of 43 rural commercial banks in Jiangsu Province, China, from 2015 to 2018, 14 indicators among 3 dimensions-coverage, business implementation and service quality-were selected to establish the inclusive finance index of rural commercial banks. The impact of market competition and government intervention on the development of the inclusive finance of rural commercial banks and the mechanism were empirically tested. The heterogeneous performance of market competition and government intervention in different market conditions were also thoroughly discussed. The results show that both market competition and government intervention can help reduce the pricing level and broaden the service coverage of rural commercial banks, which can promote the development of inclusive finance. But the role of market competition has a stronger impact than that of government intervention. The heterogeneity test shows that market competition plays a more significant role in the regions with higher levels of market competition and financial development, and in the southern and central Jiangsu Province, where the economy is relatively more developed. However, in the regions with lower levels of market competition and financial development, as well as in the northern Jiangsu Province, with a relatively backward economy, government intervention significantly improves the degree of inclusive finance of rural commercial banks. Finally, we advocate that the roles of market and government should be applied according to local conditions, and the development of the inclusive finance in rural commercial banks needs to be continuously promoted.
\end{abstract}

Keywords: rural commercial banks; inclusive finance; market competition; government intervention

\section{Introduction}

Financial inclusion refers to the provision of appropriate and effective financial services to all social classes and groups in need of financial services at an affordable cost based on equal opportunity requirements and the principle of business sustainability. The development of inclusive finance is conducive to the sustained eradication of poverty [1], the narrowing of the income gap [2,3], the sustained economic growth in rural areas [4,5] and the ultimate realization of rural revitalization [6]. Since the United Nations introduced the concept of inclusive finance in 2005, the Chinese government and financial institutions have been actively promoting the development of inclusive finance in China. On 31 December 2015, the "Plan for Promoting the Development of Inclusive Finance (2016-2020)" issued by the Chinese government pointed out that market mechanisms should be respected, and the government should play the guiding role in the overall planning, coordination and fiscal support for the development of inclusive finance. On 30 June 2021, the "Opinions on Consolidating and Expanding the Achievements of Poverty Alleviation and Comprehensively Promoting Rural Revitalization with Financial Support" pointed out that, according 
to the principle of combining market-oriented operation with government policy support, the decisive role of the market should be fully utilized to promote the formation of a market-oriented and sustainable business model. It is also necessary to play the guiding role of government fiscal support to increase the enthusiasm of financial institutions in carrying out agriculture-related business. It can be seen that the market and the government are both important driving forces to promote the development of the inclusive finance of financial institutions and support the implementation of a rural revitalization strategy. In particular, rural commercial banks (RCBs), as formal financial institutions rooted in rural areas, not only shoulder their own goals of sustainable operation but also bear the social responsibility of achieving financial inclusion. Therefore, it is particularly important to clarify the influence and mechanism of market competition and government intervention on the development of inclusive finance in RCBs, which is important to determine whether they can make sustained contributions to the growth of rural residents' income and the development of inclusive finance in rural areas.

The current literature has not been clear on the driving factors for the development of inclusive finance in rural financial institutions. Some scholars have put forward that moderate competition among rural financial institutions is conducive to breaking the monopoly in rural financial markets and improving the performance of rural financial services [7]. Zhang et al. [8] indicated that when the level of competition in the rural financial market is high, the increase in the number of rural financial institutions will play a more significant role in promoting the development of inclusive finance. Beck et al. [9] found that countries with denser bank branches tend to have a higher proportion of households with financial accounts. So, developing countries should ease market access to improve the financial availability for their residents. Lin [10] stated that when the competition level in the rural loan market is higher, the growth rate of farmers' loans will also be faster. Therefore, establishing a competitive and diversified rural financial service system, encouraging and supporting a virtuous competition among rural financial institutions, will activate the vitality of rural finance and promote the development of rural inclusive finance.

However, some scholars have also pointed out that it is not enough to promote the development of inclusive finance in rural areas only by market competition. For countries undergoing an economic transition, the level of financial development in rural areas is relatively low, and therefore the level of market competition still needs to be improved, and the risks of moral hazard and adverse selection are more prominent. As a result, government intervention is required to alleviate the information asymmetry and compensate for market failure [11-13]. The research by Yang et al. [14] revealed that the government's commitment to the establishment of a credit system, the improvement of risk aversion mechanisms and implementation of supporting policies for financial institutions will benefit the development of inclusive finance in rural areas. Policies such as increasing tax reduction and exemption for rural financial institutions, dissolving their past problems and expanding the scope of refinancing to support agriculture effectively improve the degree of inclusive finance for rural financial institutions.

Due to the deep-rooted influence and constraints of the Subsidized Agricultural Credit Paradigm, it has been widely acknowledged that rural inclusive finance can only be achieved when the government takes the initiative of assisting financial institutions through fiscal intervention and other forms of subsidies, and financial institutions provide financial services to disadvantaged groups out of government policy requirements and humanitarian purposes. However, an excessive reliance on government support and the social responsibilities of rural financial institutions neglects the decisive role of the market in resource allocation, which may affect the sustainable development of inclusive finance and lead to the reduction in the vitality of rural financial institutions. Therefore, this article focuses on the driving effect of two factors on the development of inclusive finance in RCBs: market competition and government intervention. An inclusive finance index is constructed from banks' perspective to evaluate the development of inclusive 
finance in RCBs. On this basis, the way market competition and government intervention affect the inclusive finance degree of RCBs and the mechanism in empirically tested. The heterogeneity of driving factors on inclusive finance in different market environments is thoroughly investigated. We aim to clarify how market competition and government intervention work together on the development of inclusive finance in rural financial institutions, and provide policy recommendations on making good use of the roles of the market and the government in accordance with local conditions, continuously promoting the development of inclusive finance in rural areas and supporting the implementation of a rural revitalization strategy.

\section{Theoretical Analysis and Hypothesis}

Due to the wide spread of targeted customers in rural areas, RCBs have to pay different distance costs when providing inclusive financial services to customers in various geographical locations. In this case, Hotelling Model (Hotelling, 1929) is able to precisely explain how financial institutions conduct a geographic location selection in rural financial markets and the differentiated pricing of products and services. Based on the research of Zhang et al. [8] (p. 31), the Hotelling Model has been improved by introducing government intervention as an additional factor to analyze the impact of market competition and government promotion on the pricing and profitability of RCBs. The driving factors for the development of inclusive finance in RCBs can also be revealed.

First, there are the assumptions of the model:

1. Customers in a rural financial market are evenly distributed in the unit circle market. The small gaps in their qualifications are ignored. That is, customers are regarded as homogeneous in terms of financial status, loan guarantee capacity, financial literacy, social capital, etc. Only the cost difference between each customer due to distance is considered.

2. The number of commercial banks in the unit circle market is $n$, and the banks are evenly distributed. The distance between two adjacent banks is $\frac{1}{n}$.

3. Bank A and bank B are two adjacent banks. The distance between the customer and bank $\mathrm{A}$ is $x$, and the distance between the customer and bank B is $\left(\frac{1}{n}-x\right)$.

4. Customers have unit loan demands.

5. Bank $A$ is a RCB and bank $B$ is another type of commercial bank. The loan interest rates provided by bank $A$ and bank $B$ are $R_{1}$ and $R_{2}$, the loan supplies are $S_{1}$ and $S_{2}$, the profits are $\pi_{1}$ and $\pi_{2}$, and the loan marginal costs are $C_{1}$ and $C_{2}$, respectively. Since RCBs are based in rural areas and serve the local economy, they are more popular with rural customers and more familiar with local geography and industry to build closer relationship with local farmers and small and enterprises. Bank A has unique advantages in preliminary due diligence, interim maintenance management and final debt collections. Therefore, compared with bank $B$, the loan marginal cost of RCBs is lower, usually $C_{1}<C_{2}$.

6. As information asymmetry is more serious in the rural financial market, a social mechanism should be introduced which can reduce transaction costs while providing effective support for matching credit information [15]. When government intervention or assistance do not exist, RCBs need to solely bear all the cost due to distance. The amount of this cost is $t x$, which is proportional to the distance between the RCB and the customer, and the $t$ is the information cost per unit distance. When government intervention exists in the rural financial market, RCBs can lend to customers with relatively strong financial backgrounds thanks to the help of the government. A certain financial subsidization can also be provided to RCBs by the government to make up for part of the information cost. Therefore, the information cost per unit of RCBs will decrease. It is assumed that the value of the decrease in the information cost per unit is $t 1$, and the cost of the RCB is $\left(t-t_{1}\right) x$. To simplify the situation, it is assumed that banks in the same rural financial market will receive government assistance equally. In other words, when they receive financial support from the government, the reduction in information cost per unit is always $t_{1}$. A higher $t_{1}$ indicates a greater financial support to banks from the government. 
The Hotelling Model is now used to construct a model of RCBs and other banks' loan pricing and profitability for rural customers:

When there is government intervention in the market, the unit information cost of RCB A and another bank B are both $\left(t-t_{1}\right)$, and the price of the loans provided by RCB $\mathrm{A}$ is $r_{1}+\left(t-t_{1}\right) x^{2}$. The price of the loans provided by bank B is $r_{2}+\left(t-t_{1}\right)\left(\frac{1}{n}-x\right)^{2}$. When the market is in equilibrium, the price of the loans from bank A and bank B should be consistent:

$$
r_{1}+\left(t-t_{1}\right) x^{2}=r_{2}+\left(t-t_{1}\right)\left(\frac{1}{n}-x\right)^{2}
$$

The shares of the loans provided by banks A and B to customers are as follows:

$$
\begin{gathered}
S_{1}=\mathrm{x}=\frac{n\left(r_{2}-r_{1}\right)}{2\left(t-t_{1}\right)}+\frac{1}{2 n} \\
S_{2}=\frac{1}{n}-\mathrm{x}=\frac{n\left(r_{1}-r_{2}\right)}{2\left(t-t_{1}\right)}+\frac{1}{2 n}
\end{gathered}
$$

The profits of banks A and B are:

$$
\begin{gathered}
\pi_{1}=\left(r_{1}-\mathrm{c}_{1}\right) \mathrm{x}=\left(r_{1}-\mathrm{c}_{1}\right) \times\left[\frac{n\left(r_{2}-r_{1}\right)}{2\left(t-t_{1}\right)}+\frac{1}{2 n}\right] \\
\pi_{2}=\left(r_{2}-\mathrm{c}_{2}\right)\left(\frac{1}{n}-x\right)=\left(r_{2}-\mathrm{c}_{2}\right) \times\left[\frac{n\left(r_{1}-r_{2}\right)}{2\left(t-t_{1}\right)}+\frac{1}{2 n}\right]
\end{gathered}
$$

Make $\frac{\partial \pi_{1}}{\partial r_{1}}=0, \frac{\partial \pi_{2}}{\partial r_{2}}=0$, respectively. The equilibrium interest rate when bank $\mathrm{A}$ and $B$ maximize their profits is:

$$
\begin{aligned}
& r_{1}=2 r_{2}-\frac{t-t_{1}}{n^{2}}-c_{2} \\
& r_{2}=2 r_{1}-\frac{t-t_{1}}{n^{2}}-c_{1}
\end{aligned}
$$

When they are simplified, the equilibrium interest rates $r_{1}$ and $r_{2}$ of bank $\mathrm{A}$ and $\mathrm{B}$ are:

$$
\begin{aligned}
& r_{1}=\frac{t-t_{1}}{n^{2}}+\frac{2}{3} c_{1}+\frac{1}{3} c_{2} \\
& r_{2}=\frac{t-t_{1}}{n^{2}}+\frac{1}{3} c_{1}+\frac{2}{3} c_{2}
\end{aligned}
$$

After substituting Equations (8) and (9) for Equations (2) and (3), respectively, the simplified equations of the market share of bank $\mathrm{A}$ and $\mathrm{B}$ are:

$$
\begin{aligned}
& S_{1}=\frac{\mathrm{n}\left(c_{2}-c_{1}\right)}{6\left(t-t_{1}\right)}+\frac{1}{2 n} \\
& S_{2}=\frac{\mathrm{n}\left(c_{1}-c_{2}\right)}{6\left(t-t_{1}\right)}+\frac{1}{2 n}
\end{aligned}
$$

Equation (10) subtracts Equation (11) to get Equation (12):

$$
\Delta \mathrm{S}=\frac{2 \mathrm{n}\left(c_{2}-c_{1}\right)}{6\left(t-t_{1}\right)}
$$

Since $t_{1} \in[0, \mathrm{t}],\left(\mathrm{t}-t_{1}\right)>0$. Moreover, as the marginal loan cost of RCBs is lower than in other types of banks, $C_{2}-C_{1}>0$. So, it can be concluded that $\Delta S>0$. That is, the market share of RCBs is greater than that of other types of banks, which confirms the view that RCBs are the backbones of inclusive finance in the rural financial market. 
According to the interest rate of the RCB in equilibrium $r_{1}=\frac{t-t_{1}}{n^{2}}+\frac{2}{3} c_{1}+\frac{1}{3} c_{2}$, the interest rate is in direct proportion to the square of the spatial distance between financial institutions $\frac{1}{n^{2}}$, and the interest rate is inversely proportional to the number of banks in the rural financial market $n$.

Therefore, the rural financial market becomes more competitive and the loan interest rate provided by RCBs decreases as the number of banks increases. At the same time, it can be seen that the interest rate of RCBs is inversely proportional to the government financial support $t_{1}$. In other words, with more financial support from the government, RCBs can receive more compensation for information cost and be more inclined to reduce interest rates to provide financial services for more disadvantaged rural groups.

Plugging Equation (8) into Equation (4), the simplified equation of RCB A profits is:

$$
\pi_{1}=\left(r_{1}-c_{1}\right) \mathrm{x}=\left(\frac{t-t_{1}}{n^{2}}-\frac{1}{3} c_{1}+\frac{1}{3} c_{2}\right) \times\left[\frac{n\left(-\frac{1}{3} c_{1}+\frac{1}{3} c_{2}\right)}{2\left(t-t_{1}\right)}+\frac{1}{2 n}\right]
$$

Let the profits $\pi_{1}$ of the RCB take the derivative of the number of banks $n$ in the market:

$$
\frac{\partial \pi_{1}}{\partial n}=\frac{-2\left(t-t_{1}\right)}{n^{3}} \times\left[\frac{n\left(-\frac{1}{3} c_{1}+\frac{1}{3} c_{2}\right)}{2\left(t-t_{1}\right)}+\frac{1}{2 n}\right]+\left[\frac{\left(-\frac{1}{3} c_{1}+\frac{1}{3} c_{2}\right)}{2\left(t-t_{1}\right)}-\frac{1}{2 n^{2}}\right]
$$

When the number of banks in the market is large, $\frac{-2\left(t-t_{1}\right)}{n^{3}}$ and $\frac{1}{2 n^{2}}$ are close to zero and can be ignored. Therefore, Equation (14) is approximately equal to:

$$
\frac{\partial \pi_{1}}{\partial n} \approx \frac{\left(-\frac{1}{3} c_{1}+\frac{1}{3} c_{2}\right)}{2\left(t-t_{1}\right)}=\frac{c_{2}-c_{1}}{6\left(t-t_{1}\right)}
$$

As $C_{2}-C_{1}>0$ and $\left(t-t_{1}\right)>0, \frac{\partial \pi_{1}}{\partial n}>0$. So, the profit of RCB $\pi_{1}$ increases monotonically with the increasing number of banks $n$. That is, when the level of competition increases, the profits of RCBs will rise accordingly.

Meanwhile, let the profit function $\pi_{1}$ take the derivative of the reduction of information cost $t_{1}$ to analyze the relationship between profits and government support:

$$
\begin{gathered}
\frac{\partial \pi_{1}}{\partial t_{1}}=-\frac{1}{n^{2}} \times\left[\frac{n\left(-\frac{1}{3} c_{1}+\frac{1}{3} c_{2}\right)}{2\left(t-t_{1}\right)}+\frac{1}{2 n}\right]-\left(\frac{t-t_{1}}{n^{2}}-\frac{1}{3} c_{1}+\frac{1}{3} c_{2}\right) \times \frac{n\left(-\frac{1}{3} c_{1}+\frac{1}{3} c_{2}\right)}{2\left(t-t_{1}\right)^{2}} \\
=\frac{c_{1}-c_{2}}{3 n\left(t-t_{1}\right)}-\frac{1}{2 n^{3}}-\frac{n\left(-\frac{1}{3} c_{1}+\frac{1}{3} c_{2}\right)^{2}}{2\left(t-t_{1}\right)^{2}}
\end{gathered}
$$

Because $\left(c_{1}-c_{2}\right)<0,\left(\mathrm{t}-t_{1}\right)=0, \frac{1}{2 n^{3}}>0$ and $\frac{n\left(-\frac{1}{3} c_{1}+\frac{1}{3} c_{2}\right)^{2}}{2\left(t-t_{1}\right)^{2}}>0, \frac{\partial \pi_{1}}{\partial t_{1}}<0$. That is, the profit of RCB $\pi_{1}$ decreases monotonously with the reduction of information cost $t_{1}$, and therefore the increase in government support will eventually lead to a decline in the profit level of RCBs.

Based on the discussion above, on the influence of rural financial market competition and government financial intervention on the development of inclusive finance in RCBs, we make the following observations:

First, with the gradual increase in the number of financial institutions in the rural financial market, the scope of rural financial services has been expanded. The spatial distance among different financial institutions has been narrowed, which reduces the distance cost for rural customers and alleviates financial exclusion due to distance. As a result, disadvantaged customers have equal access to financial services, which promotes the development of inclusive finance in rural areas.

Second, the increase in the number of financial institutions has made competition in the rural financial market fiercer, and the overall fixed transaction costs in the market could 
be shared. On the one hand, RCBs have made timely adjustments by reducing the interest rate, expanding the financial service and digging deeper into the lower and smaller credit market in response to the increased market competition. On the other hand, government intervention can directly decrease RCBs' information search costs and create a better credit environment to reduce the loan risk premium caused by information asymmetry. Therefore, both the increased competition in the rural financial market and more financial support from the government will lead to the reduction in interest rates and the expansion in financial service coverage of RCBs, which is in line with the service requirements of inclusive finance: reducing the cost of obtaining financial services for disadvantaged groups such as farmers, small and micro enterprises, and urban low-income earners. In this way, disadvantaged customers who need loans but can only afford lower interest rates will also have the chance to be included in the scope of inclusive finance, which will effectively alleviate financial exclusion due to pricing and promote the development of inclusive finance in rural areas.

Last but not least, with the return of large commercial banks in the rural financial market and the continuous establishment of new rural financial institutions, a diversified situation in rural financial markets has been gradually formed and competition has become increasingly fierce. The initial approach of relying on the government's assistance to financial institutions to develop inclusive finance will not be sustainable. According to the derivative results of $n$ and $t_{1}$ to the RCBs' profits, if RCBs choose to rely on government assistance for a long time, their profits will be reduced, but the intensified market competition will help to increase the profits of RCBs. Therefore, although current government intervention can still reduce the interest rate and expand the scope of services of $\mathrm{RCBs}$ to a certain extent, in the long term, market competition is the key to promoting the development of rural inclusive finance, which needs to be transformed from "governmentsubsidized finance" to "market-oriented finance". Only by gradually strengthening the financial institutions' competitiveness can they achieve a higher level of inclusive finance while obtaining higher operating profits and maintaining business sustainability.

Based on the analysis above, the following hypotheses are proposed:

Hypothesis 1. In the rural financial market, both the level of market competition and the extent of government subsidization have a positive effect on the inclusive finance degree of RCBs. However, market competition is the key factor in promoting inclusive finance, and a market-oriented approach is conducive to the realization of the business sustainability of RCBs.

Hypothesis 2. The increase in market competition and government subsidization will increase the inclusive finance degree by reducing the loan pricing of RCBs and broadening their service coverage.

\section{Variable Selection and Research Methodology}

\subsection{Data Source}

The data used in this paper was obtained from rural commercial banks throughout various counties in Jiangsu Province, China. Questionnaires were distributed to these banks to collect data including basic information, business situation, operating condition, inclusive finance and other relevant data from 2015 to 2018. After removing the responses with significant missing data and abnormal outliers, the panel data of 43 RCBs were retained. The macroeconomic data at the county level, such as economy, population and region, were obtained by referring to the "Jiangsu Statistical Yearbook" and "China County Statistical Yearbook (County and City Volume)" of the relevant years.

\subsection{Variable Selection}

\subsubsection{Explained Variable: Inclusive Finance Index of RCBs (insIFI)}

Based on the inclusive finance index system constructed by the People's Bank of China, relevant indicators that can be refined to the institutional level were selected, containing 14 indicators of 3 dimensions: coverage, business implementation and service 
quality (Table 1). The coefficient of variation method was used to give objective weight to the 14 indicators, and the linear threshold method was then applied to conduct a dimensionless treatment on each index, and finally an inclusive finance index of RCBs in Jiangsu Province was established through an anti-Euclidean distance formula (Firstly, the standard deviation and mean value of 14 indicators of each RCB were used to calculate the coefficient of variation, $V_{\mathrm{i}}=\delta_{i} / \bar{X}_{i},(i=1,2,3 \ldots 14)$, and the coefficient of variation was summed to get the weight of each indicator, $w_{i}=V_{\mathrm{i}} / \sum_{i=1}^{14} V_{\mathrm{i}}$; then, the linear threshold method was used to conduct a dimensionless treatment for 14 indicators, $d_{i}=w_{i} *$ $\left(A_{i}-M I N_{i}\right) /\left(M A X_{i}-M I N_{i}\right)$, where $A_{i}$ is the actual observed value of indicator $i$, and $M A X_{i}$ and $M I N_{i}$ are the most favorable and the most unfavorable observed values; finally, the anti-Euclidean distance formula was used to establish the inclusive financial index of RCBs of Jiangsu Province, insIFI $\left.=1-\frac{\sqrt{\left\{\left(\mathrm{w}_{1}-\mathrm{d}_{1}\right)^{2}+\left(\mathrm{w}_{2}-\mathrm{d}_{2}\right)^{2}+\ldots++\left(\mathrm{w}_{\mathrm{n}}-\mathrm{d}_{\mathrm{n}}\right)^{2}\right\}}}{\sqrt{\left\{\mathrm{w}_{1}{ }^{2}+\mathrm{w}_{2}{ }^{2}+\ldots+\mathrm{w}_{\mathrm{n}}{ }^{2}\right\}}}\right)$. The index is between 0 and 1 , where 0 indicates complete financial exclusion and 1 indicates no financial exclusion at all. A higher value represents a higher level of inclusive finance in RCBs.

Table 1. Inclusive Finance Index System of RCBs.

\begin{tabular}{|c|c|c|c|}
\hline $\begin{array}{l}\text { Evaluation } \\
\text { Dimensions }\end{array}$ & Indicators & Mean & $\begin{array}{l}\text { Standard } \\
\text { Deviation }\end{array}$ \\
\hline \multirow{8}{*}{ Coverage } & Bank Branches per 10,000 People & 0.47 & 0.16 \\
\hline & Bank Branches per Square Kilometer & 0.03 & 0.02 \\
\hline & ATMs per 10,000 People & 1.42 & 0.51 \\
\hline & ATMs per Square Kilometer & 0.11 & 0.08 \\
\hline & Bank Clerks per 10,000 People & 7.05 & 3.36 \\
\hline & Bank Clerks per Square Kilometer & 0.54 & 0.47 \\
\hline & Service Stations per 10,000 People & 3.05 & 1.84 \\
\hline & Service Stations per Square Kilometer & 0.20 & 0.12 \\
\hline \multirow{3}{*}{$\begin{array}{l}\text { Business } \\
\text { Implementation }\end{array}$} & Percentage of Loans to Farmers & 29.29 & 15.50 \\
\hline & $\begin{array}{l}\text { Percentage of Loans to Small and Micro } \\
\text { Businesses }\end{array}$ & 36.76 & 17.25 \\
\hline & $\begin{array}{l}\text { Substitution Rate of Online to } \\
\text { Over-counter Banking }\end{array}$ & 76.32 & 10.63 \\
\hline \multirow{3}{*}{ Service Quality } & File Establishment Rate of Personal Credit & 86.46 & 16.91 \\
\hline & File Establishment Rate of Business Credit & 85.74 & 19.89 \\
\hline & Complaint Rate of Financial Services & 0.14 & 0.21 \\
\hline
\end{tabular}

Increasing the credit support for farmers and small micro-enterprises is still the key point in inclusive financial development. Therefore, in the robustness test, the percentage of loans to farmers $(f l p)$ and the percentage of loans to small and micro businesses (selp) were used as substitute variables for the inclusive finance index (insIFI) to repeat the test.

\subsubsection{Key Explanatory Variable}

1. Level of Market Competition (hhi)

In this paper, the Herfindahl index (hhi) was used to measure the level of market competition of each county in Jiangsu Province from the perspective of the number of commercial banks:

$$
h h i=\sum_{i=1}^{n}\left(\frac{n_{i}}{N}\right)^{2}
$$

where $n$ indicates the type number of commercial banks in county areas, $n_{i}$ is the number of each type of commercial bank in county areas, and $N$ indicates the total number of commercial banks in county areas. The value of $h h i$ is between 0 and 1 , and a smaller value indicates a higher level of market competition. 
In the robustness test, the level of market competition was measured again from the perspective of the asset scale of commercial banks:

$$
h h i=\sum_{i=1}^{n}\left(\frac{x_{i}}{X}\right)^{2}
$$

where $x_{i}$ is the asset scale of each commercial bank, and $X$ represents the total asset scale of commercial banks in county areas.

Because hhi can only reflect the overall level of market competition in county areas but is unable to reveal RCBs' market position in county areas where they operate. As a result, the deposit market share $(c d p)$ and the loan market share $(c l p)$ of RCBs were also used to show the trends of their market shares in county areas:

$$
\begin{aligned}
& c d p=\frac{d}{D} \times 100 \% \\
& c l p=\frac{l}{L} \times 100 \%
\end{aligned}
$$

where $d$ is the deposit balance of the RCB, $D$ is the deposit balance of the county, $l$ is the loan balance of the RCB, $L$ is the loan balance of the county. $c d p$ and $c l p$, respectively, represent the proportions of RCBs' deposits and loans in the entire banking industry of the county. Higher $c d p$ and $c l p$ values stand for the larger deposit market share and loan market share of RCBs.

\section{Government Financial Support $(f g d p)$}

Because the variables that are directly related to the government's support for financial institutions cannot be found neither in the survey data nor the statistical yearbook, the proportion of the government's fiscal expenditure in GDP in county areas is used as a substitute. This is because when the government's fiscal expenditure increases, the support for financial institutions will increase accordingly. Therefore, this variable can also reflect the government's role in promoting the development of inclusive finance for financial institutions.

\subsubsection{Influence Mechanism Variables $(M V)$}

The influence mechanism variables $M V$ in this paper include two indicators: (1) Service Pricing, expressed by the interest rate $(f r)$ of an agriculture-related loan; (2l) Service Coverage, represented by the growth rate of the number of customers (growfar) who obtained financial service from RCBs. An increasing growth rate indicates a continuous expansion of RCBs' service coverage on the basis of the past.

\subsubsection{Control Variables $(\mathrm{X})$}

The control variables in this paper were selected from the regional and institutional levels:

\section{County Agricultural Insurance Coverage Rate (insurance)}

Agriculture is a weak industry. Farmers, small and micro-enterprises and other vulnerable groups face complex natural and market risks in production and operation. The emergence and popularization of agricultural insurance can help solve the plight of vulnerable groups lacking a necessary collateral, alleviate the information asymmetry in the rural financial market and optimize the external environment of rural finance, so as to enhance the willingness of RCBs to develop inclusive finance. Therefore, the improvement of agricultural insurance coverage in county areas may have a positive impact on the degree of the inclusive finance of RCBs.

\section{County Credit Filing Rate (bkbuilding)}

The continuous development of individual and enterprise credit filing will foster a better credit environment for the rural financial market. The willingness of financial 
institutions to lend will also increase, and borrowers' speculation and defaults will decrease. Therefore, the improvement of the credit filing rate in county areas may have a positive impact on the degree of inclusive finance of RCBs.

\section{County Economic Development Level (lngdp)}

A good economic environment can enhance the positive effect of inclusive finance, reduce the credit risks caused by the economic environment and improve the stability of banks and their ability to serve disadvantaged groups. Therefore, the economic development in county areas may have a positive effect on the degree of inclusive finance of RCBs.

\section{County Primary Industry Proportion (pip)}

RCBs play an important role in supporting agriculture. When the proportion of primary industry in county areas increases, RCBs may increase their support within agricultural industry. Therefore, the proportion of primary industry is expected to have a positive effect on the degree of inclusive finance of RCBs.

\section{County Tax Level (lntax)}

Generally, high taxes would restrict banks' lending. Therefore, the tax rate is inversely proportional to the degree of inclusive finance of RCBs. Due to the difficulty in obtaining regional tax rates, the total tax revenue of the county is used as a substitute.

\section{County Per Capita Net Income (lninc)}

When the per capita net income rises, residents' demand for better financial services will also increase. Correspondingly, RCBs will improve the degree of inclusive finance and provide residents with more diverse, higher-level and better-quality financial services.

\section{County Financial Development Level (cltd)}

The degree of financial industry development in county areas reflects the utilization level of its deposit resources, that is, the efficiency of financial institutions in converting deposits into loans. Generally speaking, the development degree of the financial industry will be directly proportional to the development level of inclusive finance. This study uses the proportion of loans and deposits in county areas to measure the level of financial development.

\section{Total Asset Scale of RCBs (ass)}

Expanding the scale of bank assets and improving the quality of bank assets will help increase the profitability of banks, and they can continuously provide inclusive financial services for vulnerable groups only under the condition of sustainable operation. Therefore, the scale of asset may have a positive impact on the degree of inclusive finance of RCBs.

\section{Liquidity Ratio of RCBs (lr)}

When the liquidity ratio of a bank is higher, it indicates that its debt-paying ability is stronger. Correspondingly, the ability to serve the disadvantaged groups will be stronger. Therefore, it is predicted that the liquidity ratio is proportional to the degree of inclusive finance of RCBs.

\subsection{Sample Description}

Table 2 shows the descriptive statistic results of key variables. It can be found that the inclusive finance index of RCBs in Jiangsu Province has increased year by year, indicating that the overall level of institutional inclusive finance has been steadily increasing. However, there is a wide spread of index values ranging from 0.09 to 0.56 , which indicates that the degrees of the development of inclusive finance among different RCBs vary. After sorting the inclusive finance index of 43 RCBs by year, it is found that although the degree of inclusive finance of RCBs in northern Jiangsu has steadily increased, there is still a large gap compared with that of in southern and central Jiangsu. In terms of the levels 
of market competition from 2015 to 2018, the average values of the Herfindahl index in Jiangsu Province are $0.2375,0.2333,0.2245$ and 0.2206 , respectively. The annual decline of the index values indicates that the level of market competition in the rural market has a rising trend year by year. In addition, in terms of government financial support, the average fiscal expenditure of Jiangsu government increased year by year from 2015 to 2018. Accordingly, more financial support has been provided to RCBs to develop inclusive finance.

Table 2. Descriptive Statistical Results of Key Variables (Due to the word limit, the descriptive statistic results for all variables are available upon request).

\begin{tabular}{|c|c|c|c|c|c|c|c|}
\hline \multirow{2}{*}{ Variables } & \multirow{2}{*}{$\begin{array}{l}\text { Overall } \\
\text { Average }\end{array}$} & \multicolumn{4}{|c|}{ Annual Average } & \multirow{2}{*}{ Min } & \multirow{2}{*}{$\operatorname{Max}$} \\
\hline & & 2015 & 2016 & 2017 & 2018 & & \\
\hline $\begin{array}{l}\text { Inclusive Finance Index of Financial } \\
\text { Institutions }\end{array}$ & 0.38 & 0.36 & 0.37 & 0.38 & 0.40 & 0.09 & 0.56 \\
\hline Percentage of Loans to Farmers & 29.29 & 24.71 & 26.29 & 31.77 & 34.40 & 4.72 & 81.71 \\
\hline $\begin{array}{c}\text { Percentage of Loans to Small and } \\
\text { Micro-Businesses }\end{array}$ & 36.76 & 34.47 & 35.41 & 37.68 & 39.47 & 1.99 & 76.93 \\
\hline Market Competition Level $h h i$ & 0.23 & 0.24 & 0.23 & 0.22 & 0.22 & 0.09 & 0.37 \\
\hline Deposit Market Share & 42.90 & 45.36 & 44.22 & 42.44 & 39.59 & 17.20 & 78.84 \\
\hline Loan Market Share & 28.86 & 31.14 & 29.34 & 27.98 & 26.96 & 10.88 & 56.82 \\
\hline Government Financial Support & 13.62 & 13.53 & 13.59 & 13.64 & 13.73 & 12.86 & 14.97 \\
\hline Interest Rate of Agriculture-Related Loan & 7.83 & 8.66 & 7.91 & 7.49 & 7.26 & 5.11 & 11.76 \\
\hline Growth Rate of Customer Number & 10.90 & 8.00 & 9.66 & 11.98 & 13.96 & 1.34 & 41.96 \\
\hline
\end{tabular}

\subsection{Research Design}

Formula (21) was established to verify the relationship between the level of market competition and the government's financial support, and the degree of inclusive finance of RCBs:

$$
\operatorname{insIFI} I_{i, t}=\alpha_{0}+\alpha_{1} h h i_{i, t}+\alpha_{2} f g d p_{i, t}+\sum_{j=3}^{n} \alpha_{3} X_{j, i, t}+\varepsilon_{i, t}
$$

Two issues were involved when studying the mechanism through which the market and the government affect the degree of inclusive finance of RCBs: (1) whether the increases in the level of market competition and government financial support can reduce the service pricing and broaden the service coverage of RCBs and (2) whether a lower level of service pricing and a wider service coverage can enhance the degree of inclusive finance of RCBs. Using the methods developed by Yin et al. [16], formulas (22) to (23) were established to examine the mechanism:

$$
\begin{gathered}
M V_{i, t}=\beta_{0}+\beta_{1} h h i_{i, t}+\beta_{2} f g d p_{i, t}+\sum_{j=3}^{n} \beta_{j} X_{j, i, t}+\varepsilon_{i, t} \\
\text { insIFI }_{i, t}=\gamma_{0}+\gamma_{1} M V_{i, t}+\sum_{j=2}^{n} \gamma_{j} X_{j, i, t}+\varepsilon_{i, t}
\end{gathered}
$$

\section{Empirical Test}

\subsection{Benchmark Regression}

Column (1) in Table 3 reports on the relationship among the level of market competition, the degree of government intervention and the degree of inclusive finance of RCBs. The results show that when the level of market competition increases by $1 \%$, the inclusive finance index of RCBs will increase by $0.2323 \%$ at a $5 \%$ level of significance. When the degree of government intervention is increased by $1 \%$, the inclusive finance index of RCBs will increase by $0.0052 \%$ at a $1 \%$ level of significance. By comparing the absolute values of the two coefficients, it can be found that market competition has greater effect on the 
degree of inclusive finance of RCBs than that of government intervention $(0.2323>0.0052)$. This is because when the competition in the rural financial market is not sufficient, RCBs tend to provide financial services to customers with a stronger financial background due to profit-seeking motives. When market competition increases, RCBs will take the initiative to shift their targets to lower-end markets, which improves the development of inclusive finance. However, at this stage it is not enough to rely solely on market competition to drive the development of inclusive finance in rural areas. Government interventions such as cost subsidies and tax incentives for rural financial institutions and the financial infrastructure construction in the rural areas are beneficial to promote the rural financial supply side reform and enhance the degree of inclusive finance of rural financial institutions [17]. Market competition has a stronger driving effect on RCBs' inclusive finance than that of government intervention, which reveals the sequence in the role of market and government: market plays a key role in the allocation of rural financial resources with the guidance and support from the government. The government should not replace the market.

Table 3. Benchmark Regression.

\begin{tabular}{|c|c|c|c|c|}
\hline & (1) & (2) & (3) & (4) \\
\hline & $\begin{array}{l}\text { Inclusive Finance } \\
\text { Index of RCBs }\end{array}$ & $\begin{array}{c}\text { Coverage of } \\
\text { Inclusive Finance }\end{array}$ & $\begin{array}{c}\text { Business } \\
\text { Implementation of } \\
\text { Inclusive Finance }\end{array}$ & $\begin{array}{l}\text { Service Quality of } \\
\text { Inclusive Finance }\end{array}$ \\
\hline Market Competition & $\begin{array}{c}-0.2323 * * \\
(0.1182)\end{array}$ & $\begin{array}{l}-0.1825^{*} \\
(0.1006)\end{array}$ & $\begin{array}{l}-0.2316 \\
(0.6153)\end{array}$ & $\begin{array}{c}0.0347 \\
(0.4070)\end{array}$ \\
\hline Government Intervention & $\begin{array}{c}0.0052^{* * *} \\
(0.0015)\end{array}$ & $\begin{array}{l}0.0026^{*} \\
(0.0015)\end{array}$ & $\begin{array}{l}0.0099 * \\
(0.0051)\end{array}$ & $\begin{array}{c}0.0139 * * * \\
(0.0039)\end{array}$ \\
\hline $\begin{array}{l}\text { Agricultural Insurance } \\
\text { Coverage Rate }\end{array}$ & $\begin{array}{l}0.0003 * \\
(0.0002)\end{array}$ & $\begin{array}{c}0.0003 \\
(0.0002)\end{array}$ & $\begin{array}{c}0.0004 \\
(0.0004)\end{array}$ & $\begin{array}{c}0.0005 \\
(0.0004)\end{array}$ \\
\hline Credit File Filing Rate & $\begin{array}{l}0.0004 * \\
(0.0002)\end{array}$ & $\begin{array}{l}0.0005^{* *} \\
(0.0002)\end{array}$ & $\begin{array}{c}0.0001 \\
(0.0007)\end{array}$ & $\begin{array}{c}0.0005 \\
(0.0006)\end{array}$ \\
\hline Lngdp & $\begin{array}{c}0.0854^{* * *} \\
(0.0211)\end{array}$ & $\begin{array}{l}0.0810^{* * * *} \\
(0.0246)\end{array}$ & $\begin{array}{c}0.3445^{* * *} \\
(0.0813)\end{array}$ & $\begin{array}{l}0.1276^{* *} \\
(0.0605)\end{array}$ \\
\hline Primary Industry Proportion & $\begin{array}{l}-0.0027^{*} \\
(0.0016)\end{array}$ & $\begin{array}{c}0.0011 \\
(0.0014)\end{array}$ & $\begin{array}{c}0.0065 \\
(0.0059)\end{array}$ & $\begin{array}{l}-0.0082 \\
(0.0103)\end{array}$ \\
\hline Lntax & $\begin{array}{l}-0.0170 * \\
(0.0099)\end{array}$ & $\begin{array}{l}-0.0125 \\
(0.0149)\end{array}$ & $\begin{aligned}- & 0.0746^{* * *} \\
& (0.0271)\end{aligned}$ & $\begin{array}{c}-0.0804^{* * *} \\
(0.0288)\end{array}$ \\
\hline Per Capita Net Income & $\begin{array}{l}-0.0030 \\
(0.0066)\end{array}$ & $\begin{array}{l}-0.0070 \\
(0.0066)\end{array}$ & $\begin{array}{l}-0.0055 \\
(0.0099)\end{array}$ & $\begin{array}{c}0.0097 \\
(0.0154)\end{array}$ \\
\hline Financial Development Level & $\begin{array}{l}0.0002 * \\
(0.0001)\end{array}$ & $\begin{array}{l}-0.0000 \\
(0.0001)\end{array}$ & $\begin{aligned}-0.0003^{* * *} \\
(0.0001)\end{aligned}$ & $\begin{array}{c}0.0007 \\
(0.0005)\end{array}$ \\
\hline Total Asset Scale of RCBs & $\begin{array}{l}-0.0032 \\
(0.0081)\end{array}$ & $\begin{array}{l}-0.0036 \\
(0.0075)\end{array}$ & $\begin{array}{c}0.0123 \\
(0.0231)\end{array}$ & $\begin{array}{l}-0.0235 \\
(0.0151)\end{array}$ \\
\hline Liquidity Ratio of RCBs & $\begin{array}{l}-0.0001 \\
(0.0001)\end{array}$ & $\begin{array}{c}-0.0002 * * \\
(0.0001)\end{array}$ & $\begin{array}{l}-0.0005^{*} \\
(0.0002)\end{array}$ & $\begin{array}{c}0.0004 \\
(0.0003)\end{array}$ \\
\hline Constant & $\begin{array}{c}0.0760 \\
(0.1880)\end{array}$ & $\begin{array}{l}-0.1006 \\
(0.2866)\end{array}$ & $\begin{array}{c}-1.1437^{*} \\
(0.6199)\end{array}$ & $\begin{array}{l}1.0731^{* *} \\
(0.5267)\end{array}$ \\
\hline Observations & 172 & 172 & 172 & 172 \\
\hline$R^{2}$ & 0.5071 & 0.5075 & 0.6112 & 0.2094 \\
\hline
\end{tabular}

Note: Robust standard errors are reported in parenthesis. ${ }^{* * *},{ }^{* *}$ and ${ }^{*}$ represent significance at $1 \%, 5 \%$ and $10 \%$, respectively. The same below.

The inclusive finance index system of RCBs was constructed from three dimensions: coverage, business implementation and service quality. These three dimensions were used as the explained variables for dimensional tests. As can be seen from column (2) in Table 3, both of market competition and government intervention have a positive effect on the coverage of the inclusive finance of RCBs. This is because when the level of market competition intensifies, RCBs need to increase bank branches, purchase intelligent machines and employ more staff to widen the coverage of financial services, thereby consolidating the dominant position in the rural financial market. At the same time, more financial support 
from government to RCBs can compensate for their operating cost due to the increase of branches, machines and staff. As a result, RCBs will be more motivated to increase the coverage of inclusive finance. Columns (3) and (4) show that for every $1 \%$ increase in government financial support, the dimensions of implementation and service quality will increase by $0.0099 \%$ and $0.0139 \%$ at different levels of significance, respectively. This is because although RCBs are responsible for supporting local agriculture and small and micro-enterprises, they may still have limited enthusiasm in serving the agriculture and small and micro-enterprises because of the high risk with low return. Government financial support such as fiscal subsidies and tax incentives will plays a significant role in promoting the development of inclusive finance [18]. At the same time, the government increases expenditure to improve the construction of financial infrastructure in less developed areas, which can provide a good market environment for the sustainable development of RCBs, thereby improving the quality of inclusive finance.

\subsection{Influence Mechanism}

Table 4 examined the ways in which the market and the government had affected the degree of inclusive finance of RCBs. Columns (1) to (2) show that both of the levels of market competition and government intervention have a significant negative effect on the interest rates of RCB's agriculture-related loans. At the same time, for every $1 \%$ decrease in the interest of agriculture-related loans, the inclusive finance index increases by $0.0088 \%$ at a $1 \%$ level of significance, which proves the existence of the service pricing channel. Columns (3) to (4) show that the level of market competition and government intervention have significantly positive effects on the growth rate of $\mathrm{RCBs}^{\prime}$ customer number, and the growth rate will significantly increase the inclusive finance index, which proves the existence of service coverage channel. This is probably because when market competition intensifies, RCBs will take the initiative to reduce service price and broaden service coverage to attract more low-end customers who require loans. In addition, with more government financial supports being provided to RCBs, the dilemma of "high risk with low return" will be partially resolved, so that RCBs will be more motivated to provide financial services to a larger number of disadvantaged groups at more affordable prices. The gradual reduction in interest rates of agriculture-related loans and the effective expansion of the service coverage of RCBs also indicate that the degree of inclusive finance of RCBs has been further increased. Therefore, the increase in market competition and government financial support have improved the degree of inclusive finance by reducing the service price and broadening the service coverage of RCBs.

Table 4. Influence Mechanism Analysis (Due to the word limits, the following table only shows the results for the key explanatory variables).

\begin{tabular}{|c|c|c|c|c|}
\hline & \multicolumn{2}{|c|}{ Service Pricing Channel } & \multicolumn{2}{|c|}{ Service Coverage Channel } \\
\hline & $\begin{array}{c}\text { (1) Interest Rates of } \\
\text { Agriculture-Related } \\
\text { Loans }\end{array}$ & $\begin{array}{l}\text { (2) Inclusive Finance } \\
\text { Index of RCBs }\end{array}$ & $\begin{array}{l}\text { (3) Growth Rate of } \\
\text { Customer Number }\end{array}$ & $\begin{array}{l}\text { (4) Inclusive Finance } \\
\text { Index of RCBs }\end{array}$ \\
\hline Market Competition & $\begin{array}{l}5.1453^{* *} \\
(2.0649)\end{array}$ & & $\begin{array}{c}-28.8727^{* *} \\
(12.0318)\end{array}$ & \\
\hline Government Financial Support & $\begin{array}{c}-0.1189^{* * *} \\
(0.0359)\end{array}$ & & $\begin{array}{l}0.7827 * * * \\
(0.1933)\end{array}$ & \\
\hline $\begin{array}{l}\text { Interest Rates of } \\
\text { Agriculture-Related Loans }\end{array}$ & & $\begin{array}{l}-0.0088^{* * *} \\
(0.0032)\end{array}$ & & \\
\hline $\begin{array}{l}\text { Growth Rate of Customer } \\
\text { Number }\end{array}$ & & & & $\begin{array}{l}0.0022^{* * * *} \\
(0.0006)\end{array}$ \\
\hline Control Variable & Yes & Yes & Yes & Yes \\
\hline Observations & 172 & 172 & 172 & 172 \\
\hline$R^{2}$ & 0.4999 & 0.4664 & 0.5256 & 0.4923 \\
\hline
\end{tabular}




\subsection{Heterogeneity Analysis}

\subsubsection{Differences in the Level of Market Competition}

The mean value of all hi of sample counties was calculated. Then, the hhi of each county was compared with the mean value. If the hhi is lower than the mean value, it was divided into counties with a high market competition. Conversely, if the value is higher than the mean value, it was divided into counties with a low market competition. Sample regression was then carried out. Results are shown in Table 5. In counties with a low market competition (column (2) of Table 5), government intervention is the main motivation to promote the development of inclusive finance for RCBs. For every $1 \%$ increase in government financial support, the degree of inclusive finance of RCBs will be increased by $0.0068 \%$ at a $1 \%$ level of significance, but the role of market regulation has not been significantly exerted. In counties with a relatively high market competition (column (1) of Table 5), the market is the key in promoting the development of inclusive finance in RCBs. For every $1 \%$ decrease in the $h h i$, the degree of inclusive finance of RCBs will rise by $0.7759 \%$ at a $10 \%$ level of significance, and government intervention has not played a significant role. This may be because when there is a lack of moderate competition in the rural financial market, rural financial institutions are prone to grant loans to nonagricultural background customers to pursue higher profits [19] In this case, only through government's fiscal incentives and subsidies can RCBs be effectively motivated to assist disadvantaged groups. However, in the highly competitive rural financial market, RCBs will make good use of their advantages, such as flexibility in operating methods, lower trading costs, higher popularity among rural customers and more familiarity with local geography to constantly expend their services to lower-end markets and spontaneously provide inclusive financial services to a larger number of disadvantaged groups.

Table 5. Heterogeneity Analysis on Different Levels of Market Competition.

\begin{tabular}{|c|c|c|}
\hline & $\begin{array}{c}\text { (1) Inclusive Finance Index } \\
\text { of RCBs } \\
\text { High Level of Market } \\
\text { Competition } \\
\text { (hhi<hhi_mean) }\end{array}$ & $\begin{array}{c}\text { (2) Inclusive Finance Index } \\
\text { of RCBs } \\
\text { Low Level of Market } \\
\text { Competition } \\
\text { (hhi>hhi_mean) }\end{array}$ \\
\hline Market Competition & $\begin{array}{c}-0.7759 * \\
(0.4252)\end{array}$ & $\begin{array}{l}-0.1535 \\
(0.1865)\end{array}$ \\
\hline Government Financial & 0.0021 & $0.0068^{* * *}$ \\
\hline Support & $(0.0021)$ & $(0.0015)$ \\
\hline Control Variables & Yes & Yes \\
\hline Observations & 89 & 83 \\
\hline$R^{2}$ & 0.5479 & 0.4942 \\
\hline
\end{tabular}

Note: Robust standard errors are reported in parenthesis. ${ }^{* * *}$ and ${ }^{*}$ represent significance at $1 \%$ and $10 \%$.

\subsubsection{Differences in the Level of Financial Development}

The ratio of loan balance to deposit balance was used to measure the level of utilization of financial resources in various countries, which can reflect the level of financial development to a certain extent. Similarly, the mean value of the financial development level of the sample counties was calculated. Then, the level of each county was compared with the mean value. Counties with more than the average value are classified as those with a higher degree of financial development and vice versa. A sample regression was then undertaken. According to the result in column (1) of Table 6, it can be found that when the level of a county's financial development is low, the coefficient of the level of market competition does not pass the significance test. For every $1 \%$ increase in government financial support, the degree of RCB's inclusive finance will increase by $0.0045 \%$ at a $5 \%$ level of significance. The results of column (2) in Table 6 show that when the level of financial development in a county is relatively high, both market competition and government intervention simultaneously promote the development of the inclusive finance of RCBs and the market has played a more important role. This is because when the level of financial 
development in a county is low, the financial resources of the county will be less efficiently used. Accordingly, the ability of converting deposits into loans will also be limited. In this situation, the government's regulation role is needed to improve economic efficiency, and then increase the support of RCBs to disadvantaged groups. For counties where the use of financial resources is more efficient, RCBs are more inclined to allocate resources spontaneously, thereby enhancing the degree of inclusive finance.

Table 6. Heterogeneity Analysis on Different Levels of Financial Development.

\begin{tabular}{ccc}
\hline & $\begin{array}{c}\text { (1) Inclusive Finance Index } \\
\text { of RCBs }\end{array}$ & $\begin{array}{c}\text { (2) Inclusive Finance Index } \\
\text { of RCBs }\end{array}$ \\
\cline { 2 - 3 } & $\begin{array}{c}\text { Low Level of Financial } \\
\text { Development } \\
(\text { cltd<cltd_mean })\end{array}$ & $\begin{array}{c}\text { High Level of Financial } \\
\text { Development } \\
(\text { cltd }>\text { cltd_mean })\end{array}$ \\
\hline Market Competition & -0.2607 & $-0.2847^{* *}$ \\
Government Financial & $(0.1784)$ & $(0.1417)$ \\
Support & $0.0045^{* *}$ & $0.0059^{* *}$ \\
Control Variables & $(0.0018)$ & $(0.0023)$ \\
Observations & Yes & Yes \\
$R^{2}$ & 94 & 78 \\
\hline
\end{tabular}

Note: Robust standard errors are reported in parenthesis. ${ }^{* *}$ represents significance at $5 \%$.

\subsubsection{Differences in the Regions Where RCBs Are Located}

The 43 RCBs sampled for this paper are located in three regions across Jiangsu Province: 10 in the south, 12 in the central and 21 in the north. A sample regression was carried out, and the results in Table 7 show that for those located in the southern and central regions in Jiangsu Province, market competition is the main driving factor for the development of inclusive finance. Meanwhile, in the less developed areas in the north, government intervention is still necessary at this stage to enhance RCBs' enthusiasm for assisting the agriculture and small and micro-enterprises.

Table 7. Heterogeneity Analysis on Different Regions.

\begin{tabular}{cccc}
\hline & $\begin{array}{c}\text { (1) Inclusive Finance } \\
\text { Index of RCBs }\end{array}$ & $\begin{array}{c}\text { (2) Inclusive Finance } \\
\text { Index of RCBs }\end{array}$ & $\begin{array}{c}\text { (3) Inclusive Finance } \\
\text { Index of RCBs }\end{array}$ \\
\cline { 2 - 4 } & Southern & Central & Northern \\
\hline Market Competition & $-0.9857^{* * *}$ & $-0.7237^{* * *}$ & 0.0340 \\
Government & $(0.2685)$ & $(0.1811)$ & $(0.1636)$ \\
Financial Support & -0.0030 & -0.0037 & $0.0057^{* *}$ \\
Control Variables & $(0.0053)$ & $(0.0029)$ & $(0.0026)$ \\
Observations & Yes & Yes & Yes \\
$R^{2}$ & 40 & 48 & 84 \\
\hline Note: Robust standard errors are reported in parenthesis. & *** and ${ }^{* *}$ represent significance at $1 \%$ and $5 \%$.
\end{tabular}

\subsection{Robustness Test}

\subsubsection{Robustness Test for Replacement Regression Model}

The random effect model was used in the benchmark regression. However, since the $R C B^{\prime}$ inclusive finance index is between 0 and 1 , the explained variable is limited and truncated, and therefore the random effect Tobit Model was used to test the robustness of the benchmark regression. The results are shown in Table 8. Column (1) is the result using the random effect model, and column (2) is a random effect Tobit model. By comparison, it is found that the results obtained by the two different models are generally consistent. The hhi still negatively affects the degree of inclusive finance of RCBs in a significant manner, 
and government financial support is still positively affected in a significant manner. The results of benchmark regression are relatively robust.

Table 8. Robustness Test for the Replacement Regression Model.

\begin{tabular}{ccc}
\hline & $\begin{array}{c}\text { (1) Inclusive Finance Index } \\
\text { of RCBs }\end{array}$ & $\begin{array}{c}\text { (2) Inclusive Finance Index } \\
\text { of RCBs }\end{array}$ \\
\hline Market Competition & $-0.2323^{* * *}$ & $-0.2247^{*}$ \\
Government Financial & $(0.1182)$ & $(0.1152)$ \\
Support & $0.0052^{* * *}$ & $0.0054^{* * *}$ \\
Control Variables & $(0.0015)$ & $(0.0014)$ \\
Observations & Yes & Yes \\
$R^{2}$ & 172 & 172 \\
Model & 0.5071 & $/$ \\
& Re & Xttobit \\
\hline
\end{tabular}

Note: Robust standard errors are reported in parenthesis. ${ }^{* * *},{ }^{* *}$ and ${ }^{*}$ represent significance at $1 \%, 5 \%$ and $10 \%$, respectively.

\subsubsection{Robustness Test of Alternative Explained Variables}

The percentage of loans to farmers and small and micro-enterprises were used to replace the inclusive finance index to verify how the levels of market competition and government financial support affect $\mathrm{RCBs}^{\prime}$ financial supports for farmers and small and micro-enterprises. The results show that the coefficients of $h$ hi in columns (2) and (3) of Table 9 are still negative and none of them pass the significance test. The coefficients of government financial support are all positive, but there is only a significant impact on the increase in the percentage of loans to small and micro-enterprises. This shows that at the current stage, market competition is not enough for RCBs to spontaneously increase the financial support to disadvantaged groups. However, government intervention can provide a certain degree of incentive for RCBs to serve disadvantaged groups.

Table 9. Robustness Test of Alternative Explained Variables.

\begin{tabular}{cccc}
\hline & $\begin{array}{c}\text { (1) Inclusive Finance } \\
\text { Index of RCBs }\end{array}$ & $\begin{array}{c}\text { (2) Percentage of } \\
\text { Loans to Farmers }\end{array}$ & $\begin{array}{c}\text { (3) Percentage of } \\
\text { Loans to Small and } \\
\text { Micro Enterprises }\end{array}$ \\
\hline Market Competition & $-0.2123^{* *}$ & -33.9584 & -9.2937 \\
Government & $(0.1182)$ & $(78.4947)$ & $(32.4684)$ \\
Financial Support & $0.0052^{* * *}$ & 0.3694 & $0.8649^{* *}$ \\
Control Variables & $(0.0015)$ & $(0.7276)$ & $(0.3772)$ \\
Observations & Yes & Yes & Yes \\
$R^{2}$ & 172 & 172 & 172 \\
Note: Robust standard errors are reported in parenthesis. ${ }^{* * *}$ and & 0.4547 & 0.3490 \\
\hline
\end{tabular}

\subsubsection{Robustness Test of Alternative Explanatory Variables}

The hhi 2 calculated with the asset scale of banks in the counties, and RCBs' market shares of deposits and loans were used to replace the level of market competition in the benchmark regression to verify the robustness of regression results. The results are shown in Table 10. Column (1) is the benchmark regression. The explanatory variable in column (2) is the hhi2 of the banks' asset scale. The results show that the direction and significance of the coefficient of hhi2 remain the same as that of hhi in column (1). In columns (3) and (4), both of the increases in RCBs' market shares of deposits and loans have a significantly negative effect on the inclusive finance index of RCBs. This result is similar to the benchmark regression result shown in column (1). This is because when RCBs' market shares of deposits and loans increase, the degree of oligopoly in the rural financial market rises, which leads to a decrease in market competition. As a result, the degree of inclusive finance decreases. At the same time, government's financial support, 
as shown in columns (2) to (4), still positively affects the degree of inclusive finance of RCBs at a $1 \%$ level of significance, indicating that the benchmark regression has a strong robustness.

Table 10. Robustness Test of Alternative Explanatory Variables.

\begin{tabular}{ccccc}
\hline & $\mathbf{( 1 )}$ & $\mathbf{( 2 )}$ & $\mathbf{( 3 )}$ & $\mathbf{( 4 )}$ \\
\cline { 2 - 5 } & $\begin{array}{c}\text { Inclusive Finance } \\
\text { Index of RCBs }\end{array}$ & $\begin{array}{c}\text { Inclusive Finance } \\
\text { Index of RCBs }\end{array}$ & $\begin{array}{c}\text { Inclusive Finance } \\
\text { Index of RCBs }\end{array}$ & $\begin{array}{c}\text { Inclusive Finance } \\
\text { Index of RCBs }\end{array}$ \\
\hline Market Competition & $-0.2123^{* *}$ & $-0.2507^{*}$ & \\
& $(0.1182)$ & $(0.1447)$ & $-0.0008^{*}$ \\
Deposit Market Share of RCBs & & & $(0.0005)$ & $-0.0011^{*}$ \\
Loan Market Share of RCBs & & & $(0.0007)$ \\
Government Financial Support & $0.0052^{* * *}$ & $0.0047^{* * *}$ & $0.0046^{* * *}$ & $0.0049^{* * *}$ \\
Control Variables & $(0.0015)$ & $(0.0011)$ & $(0.0013)$ & $(0.0013)$ \\
Observations & Yes & Yes & 172 & 172 \\
$R^{2}$ & 172 & 172 & 0.5416 & 0.5427 \\
\hline
\end{tabular}

Note: Robust standard errors are reported in parenthesis. ${ }^{* * *}, * *$ and ${ }^{*}$ represent significance at $1 \%, 5 \%$ and $10 \%$, respectively.

\section{Conclusions and Recommendations}

\subsection{Conclusions}

Based on the panel data of RCBs in 43 counties in Jiangsu Province from 2015 to 2018, this paper selected 14 indicators in three dimensions: (1) coverage of inclusive finance, (2) business implementation of inclusive finance and (3) service quality of inclusive finance to construct the inclusive finance index of RCBs. An empirical study on how the market competition level and government financial support affect the degree of inclusive finance of RCBs was undertaken. In addition, the heterogeneous role of the market and the government in promoting the financial inclusion of RCBs in different market environments was also discussed. The results reflect that both of the intensification of market competition and the increase in government financial support reduce the interest rate of agriculturerelated loans of RCBs and broaden the coverage of financial services, thus playing a positive role in improving the degree of inclusive finance of RCBs, and the driving effect of market competition is greater than that of government intervention. Meanwhile, when moderate competition does not exist, the use of financial resources is inefficient, and in the less developed area in northern Jiangsu Province, government financial incentives may effectively improve the degree of inclusive finance of RCBs. When the level of market competition and financial development is relatively high, and in the more developed and moderately developed areas in southern and central Jiangsu Province, RCBs may spontaneously increase the supply of inclusive financial services to disadvantaged groups to compete in the market.

\subsection{Recommendations}

At the current stage, the competition in the rural market and the local government intervention are both the driving factors for the development of the inclusive finance of RCBs. However, the relationship between the market and the government should be carefully managed by acknowledging the decisive role of the market in resource allocation and clarifying the boundary of the government's function in promoting inclusive finance in rural regions. Excessive government intervention for institutions should be prevented to deliver the government's enhancement function in the rural financial market. 
5.2.1. Adhering to the Market-Oriented Direction and Cultivating a Competitive Rural Inclusive Finance Market

The barriers to enter the rural inclusive finance market need to be continuously reduced to allow traditional financial institutions to join the rural financial market, so as to establish more branches and provide an agriculture-related financial service. Innovated rural financial institutions and private capital would be invited to enter the inclusive finance system, so as to form a fairly and orderly competitive environment, which meets the diversified and multi-level financial needs in rural areas. The monopoly of RCBs needs to be broken down to improve the vitality of the rural financial market, which may encourage RCBs to shift the focus of service, target disadvantage groups and boost the incentives to develop inclusive finance.

5.2.2. Making up for Market Failures and Improving Government Financial and Monetary Policy Support

Government should introduce corresponding tax incentives, financial rewards and subsides to RCBs for carrying out inclusive finance. At the same time, differentiated bank reserve requirements for deposits, re-lending to support agriculture and rediscount policies should be used to compensate for the risks and costs of RCBs, which will increase their initiative in serving disadvantaged groups.

\subsubsection{Beware of Excessive Government Intervention and Avoid the Absence of Government Intervention}

On the one hand, it is necessary to clarify the boundaries of the government's function to promote the development of inclusive finance, such as the scope, the intensity and the methods. In particular, the government should grant RCBs a certain degree of decisionmaking autonomy and appropriately reduce the direct intervention in their day-to-day business activities. On the other hand, government intervention should not be absent as it plays an important role in strengthening the establishment of rural financial facilities. Specifically, the government should continue to reinforce the development of payment and settlement systems, improve the enactment of financial laws and regulations, fulfill the establishment of a credit system and improve the construction of financial supervision systems.

\subsubsection{Making Good Use of the Roles of the Market and the Government According to Local Conditions}

In the areas where market competition and finance development are relatively high and the economy is relatively advanced, the market's role in resource allocation should be emphasized. In the meantime, the government's main function is to maintain a fair competition in the financial market, and the direct fiscal interventions to financial institutions should be reduced accordingly. In the regions where market competition is missing, with a relatively low level of efficiency in resource allocation and economy development, government intervention should be the focus of rural inclusive finance to alleviate market failures. As a result, a certain degree of fiscal and tax incentives from the government to rural financial intuitions will increase their enthusiasm to promote inclusive finance.

Author Contributions: Conceptualization, C.Z.; methodology, C.Z.; software, C.Z.; validation, C.Z.; formal analysis, C.Z.; data provider, X.D.; fund host, X.D.; investigation, C.Z. and L.D.; data curation, X.D. and C.Z.; writing-original draft preparation, C.Z.; writing-review and editing, X.D., L.D. and C.L. All authors have read and agreed to the published version of the manuscript.

Funding: The research for this paper was supported by the National Natural Science Foundation of China (No. 72073067).

Data Availability Statement: The data presented in this study are available on request from the corresponding author. The data are not publicly available because they are the primary data obtained by the corresponding author's research group through investigation, and the funding has not yet been concluded. 
Conflicts of Interest: The authors declare no conflict of interest.

\section{References}

1. Jinmian, H.; Jiaqi, W.; Xiangqiang, M. Effects of Farmers' Participation in Inclusive Finance on Their Vulnerability to Poverty: Evidence from Qinba Poverty-Stricken Area in China. EMFT 2019, 55, 998-1013.

2. Yaning, L.; Qingqing, Z.; Liwei, X. Has Inclusive Finance Narrowed the Income Gap between Urban and Rural Areas? An Empirical Analysis Based on Coastal and Noncoastal Regions' Panel Data. J. Coastal. Res. 2020, 106, 305-308.

3. Chaohua, H.; Hongyan, D. Urbanization, Inclusive Finance and Urban-rural Income Gap. Appl. Econ. Lett. 2021. [CrossRef]

4. Guangyou, Z.; Kuangxiong, G.; Sumei, L.; Guohu, X. Inclusive Finance, Human Capital and Regional Economic Growth in China. Sustainability 2018, 10, 1194. [CrossRef]

5. Dahiya, S.; Kumar, M. Linkage between Financial Inclusion and Economic Growth: An Empirical Study of the Emerging Indian Economy. Vis. J. Bus. Persp. 2020, 24, 184-193. [CrossRef]

6. Huang, Q. Realization Path for Inclusive Finance to Support Rural Revitalization in Poverty-stricken Areas. ASAR 2021, 13, 1-5.

7. Tao, W.; Jishan, B.; Xiaohua, W. An Analysis of the Competitive Relationship of the Rural Financial Market in China Based on the Lotka-Volterra Model. Chin. Rur. Econ. 2015, 10, 42-54.

8. Zhengping, Z.; Dandan, Y. Market Competition, Expansion of New Rural Financial Institutions and the Development of Inclusive Finance: Inspection and Comparison Based on the Provincial-level Panel Data. Chin. Rur. Econ. 2017, 1, 30-43.

9. Beck, T.; Demirguc-Kunt, A.; Honohan, P. Access to Financial Services: Measurement, Impact and Policies. Word Bank Res. Obser. 2009, 24, 119-145. [CrossRef]

10. Yana, L. The Influence of Rural Credit Cooperatives' Market Competition on Farmer's Loan Supply: Based on the Measurement and Analysis of Lerner Index and Boone Index. South China Finance 2019, 6, 83-91.

11. Hellmann, T.F.; Murdock, K.C.; Stiglitz, J.E. Liberalization, Moral Hazard in Banking and Prudential Regulation: Are Capital Requirements Enough? AER 2000, 90, 147-165. [CrossRef]

12. Ndikumana, L. Distributional Conflict, the State and Peace Building in Burundi. Round Table 2005, 94, 413-427. [CrossRef]

13. Bhatia, A.; Bhabha, H. India's Aadhaar Scheme and the Promise of Inclusive Social Protection. ODS 2017, 45, 64-79. [CrossRef]

14. Yekun, Y.; Jianfeng, J. The Role of Government in Rural Financial Innovation-A Case Study of Yunfu City. South China Finance 2013, 8, 66-68.

15. Yaron, J. What Makes Rural Finance Institutions Successful. World Bank Res. Obser. 1994, 9, 49-70. [CrossRef]

16. Zhichao, Y.; Donghao, Z. Financial Inclusion, Household Poverty and Vulnerability. CEQ 2020, $20,153-172$.

17. Jiujie, M.; Benjian, W.; Hairong, Z. Role of the State in Financial Inclusion: International Experience and China's Reform Orientation. J. FAFU Phil. Soc. Sci. 2016, 19, 7-13.

18. Pan, D.; Wangdui, N.M.; Nan, C. Evaluation on the Effect of Fiscal Policies Supporting the Development of Inclusive Finance: An Analysis Based on the Perspective of Financial Incentives for Agriculture-related Loan Increment of County Financial Institutions. Wuhan Financ. 2020, 10, 68-73.

19. Xiong, W.; Qian, L. Banking Competition, Expansion of New Rural Financial Institutions and Financial Inclusion Development. Jiangsu Agric. Sci. 2018, 46, 297-302. 